\title{
Sociological Status of Onion Growing Farmers in Akola District of Maharashtra, India
}

\author{
Sudarshan C. Awatade ${ }^{1 *}$, Anindita Saha ${ }^{1}$ and Digvijay S. Dhakre ${ }^{2}$ \\ ${ }^{1}$ Department of Agricultural Extension, ${ }^{2}$ Department of Agricultural Economic and \\ Agricultural Statistics, Palli Shiksha Bhavana (Institute of Agriculture), Visva-Bharati, \\ Sriniketan, Bolpur, West Bengal-731236, India \\ *Corresponding author
}

\section{A B S T R A C T}

The study was conducted in Akola district of Maharashtra, collecting data from 120 onion growers using structured interview schedule. Randomly 24 onion growing farmers were

\section{Keywords}

Onion, Akola,

Maharashtra,

Respondents

Article Info

Accepted:

04 February 2018

Available Online:

10 March 2018 selected from each selected five villages constituted a sample size of 120 farmers. The majority of the respondents $(70.83 \%)$ found to be middle age group (between 37 to 56 years) with the majority of OBC caste $(59.17 \%)$ of the selected onion growers, most of the selected farmers $(71.67 \%)$ were having middle level of education. The mainstream of the respondents were having (78.33\%) medium size of family (3-8) members and most of the respondents $(89.16 \%)$ are having only agriculture as an occupation. Where, majority of the respondents $(75.83 \%)$ were having 8 to 19 years' experience in onion farming. But, it is quite obvious that $85 \%$ of respondents were not associated with any organization by any way of membership and involvement. Most of the respondents (75.84\%) were found having medium (1-5 ha) size of farm where $(61.67 \%)$ of respondents were having their income in the medium range between Rs. 50,000 to $1,00,000$ and $66.67 \%$ of the respondents belonged to medium average annual yield category. In this context, extension services can be consider as remarkable factor for enhancing productivity and making farmers self-sufficient in farming by providing need based information.

\section{Introduction}

Onion (Allium ascalonium L) is the largest produced and consumed vegetable and is used in all our traditional cuisine and culinary preparations not only in India but all around the world. Therefore, onion is popularly referred as "Queen of Kitchen." Onion is consumed by all classes of people- poor and rich and hence, assumes a place of essential item. Among fresh vegetables, onion, tomato, and mushroom are reported to be highly export-competitive (PIU, 2013). A global review of major vegetables show that onion ranks second to tomatoes in area under cultivation. Over 40 million tonnes of onion were produced worldwide in 1998, covering about 4.5 million hectares (PIU, 2013). Onion is a crop of national importance and considerable attention has been paid by the National Agricultural Research System (NARS) of the country to the improvement of 
this crop. The National Horticultural Research Development Foundation, sponsored by the apex level co-operative called the National Agricultural Co-operative Marketing Federation of India (NAFED), and the National Research Centre on Onion and Garlic of the Indian Council of Agricultural Research (ICAR) are engaged in systematic efforts for the improvement of onion (NIAM, 2013). Maharashtra State has a diversified cropping pattern in different regions depending upon agro - climatic conditions onion being an important commercial cash crop grown in almost all the regions. According to the action plan KVK, Akola, 2013-14, it was reported that onion is leading as first in area under cultivation i.e., 1600 ha and highest production of $33,60,000 \mathrm{Kg} \mathrm{ha}^{-1}$, among all the vegetable crops grown in Akola district but the productivity of the crop is reported to be dwindling which might be due lack of information about the crop.

However, onion crop poses a number of constraints in development such as low adoption of improved technology, less knowledge of standard package of practices and good agriculture practices for promotion of export, distress sale due to lack of information about the arrival of produce and price, marketing facilities, storage and transportation etc (Patil et al., 2012; Gadge and Lawande, 2012). Hence, it was found quite interesting to study the sociological status of onion farmers in Akola district of Maharashtra.

\section{Materials and Methods}

The study was conducted during the year 2015 in Akola district of the Maharashtra. 'Patur' block of Akola district was selected with five villages namely Aagikheda, Ambashi, Khamkheda, Aalegoan and Babhulgoan according to the area of onion cultivation in the villages. List of families engaged with onion cultivation was prepared as well as 120 were selected as respondents for collection of data. The data were collected by personal interview with the help of pre-tested structure Interview schedule. The statistical measures such as percentage, mean score, standard deviation were used.

\section{Results and Discussion}

In the present study, the age status of the respondents has been categorized into three categories i.e. Young (below the age of 37yrs), middle (between the age of 37 to $56 \mathrm{yrs}$.) and old (above the age of $56 \mathrm{yrs}$ ).

In the present study it is found that majority of the respondents belonged to the 'middle age' group $(70.83 \%)$ followed by 'old age' $(16.67 \%)$ and 'young farmers' group (12.2\%) (Table 1).

The majority of the 71 respondents $(59.17 \%)$ belonged to other backward caste (OBC) followed by 19 respondents $(15.83 \%)$ to National Tribe (NT), 16 respondents $(13.33 \%)$ to Scheduled Caste, 9 respondents $(7.50 \%)$ to Schedule Tribe and 5 respondents $(4.17 \%)$ to General Caste (Table 2).

Most of the respondents having up to higher secondary level of education with frequency of $86(71.67 \%)$ followed by $22(18.34 \%)$ respondents having up to primary level of education with and $12(10 \%)$ of respondents having above higher secondary level of education (Table 3 ).

The 73 of the respondents have nuclear type of family i.e. (60.83\%) and remaining 47 respondents were found to be having joint family type i.e. $(39.17 \%)$. The nuclear types of family were having the highest consistency level of the variable, under the family type distribution (Table 4). 


\section{Table.1 Distribution of the respondents according to their age}

\begin{tabular}{|c|c|c|c|}
\hline Sl. no. & Category & Frequency & $(\%)$ \\
\hline 1 & Young (below-37 yrs) & 15 & 12.5 \\
\hline 2 & Middle aged (37-56 yrs) & 85 & 70.83 \\
\hline 3 & Old (above-56 yrs) & 20 & 16.67 \\
\hline 4 & Total & 120 & 100.00 \\
\hline
\end{tabular}

\section{Table.2 Distribution of respondents according to their caste}

\begin{tabular}{|c|}
\hline Sl. no. \\
\hline 1. \\
\hline 2. \\
\hline 3. \\
\hline 4. \\
\hline 5. \\
\hline
\end{tabular}

Category
General
OBC
NT
SC
ST

Frequency

5

71

19

16

9
$(\%)$

04.17

59.17

15.83

13.33

7.50

\section{Table.3 Distribution of the respondents according to their education}

\begin{tabular}{|c|}
\hline Sl. no. \\
\hline 1. \\
\hline 2. \\
\hline 3. \\
\hline 4. \\
\hline
\end{tabular}

\begin{tabular}{|c|}
\hline Category \\
\hline Up to Primary \\
\hline Up to Higher secondary \\
\hline Above Higher secondary \\
Total
\end{tabular}

\section{Frequency}

22

86

12

120
$(\%)$

18.33

71.67

10.00

100.00

Table.4 Distribution of the respondents according to their family type

\begin{tabular}{|c|}
\hline Sl. no. \\
\hline 1. \\
\hline 2. \\
\hline
\end{tabular}

\begin{tabular}{|c|}
\hline Category \\
\hline Joint \\
\hline Nuclear \\
\hline
\end{tabular}

Frequency

$(\%)$

Nuclear

73

60.83

\section{Table.5 Distribution of the respondents according to their family size}

\begin{tabular}{|c|c|c|c|}
\hline Sl. no. & Category & Frequency & $\mathbf{( \% )}$ \\
\hline $\mathbf{1}$ & Small (below- 3) & 10 & 8.33 \\
\hline $\mathbf{2}$ & Medium (between- 3 to 8) & 94 & 78.33 \\
\hline $\mathbf{3}$ & Large (above- 8) & 16 & 13.33 \\
\hline
\end{tabular}

\section{Table.6 Distribution of the respondents according to their occupation}

\begin{tabular}{|c|c|c|c|}
\hline S. & Category & Frequency & $\mathbf{( \% )}$ \\
\hline no. & Farming only & 107 & 89.16 \\
\hline 1. & Farming and local transport & 04 & 03.33 \\
\hline 2. & Farming and business & 04 & 03.33 \\
\hline 3. & Fovt. Job and Farming & 05 & 04.17 \\
\hline 4. & Total & 120 & 100 \\
\hline
\end{tabular}


Table.7 Distribution of respondents according to their onion farming experience

\begin{tabular}{|c|}
\hline Sr. no \\
\hline 1 \\
\hline 2 \\
\hline 3 \\
\hline
\end{tabular}

.

\section{Category}

Less (>08 yrs.)

Moderate (08 to 19 yrs.)

Highly (<19 yrs.)

Total
Frequency

$(\%)$

15

17

92

75.83

11

9.17

120

\begin{tabular}{|c|c|c|c|}
\hline \multicolumn{4}{|c|}{ Table.8 Distribution of respondents according to Social Participation } \\
\hline Sl. & Social participation & Frequency & $(\%)$ \\
\hline no. & Not member of any organization & 102 & 85.00 \\
\hline 1. & co-operative society & 7 & 05.83 \\
\hline 2. & Panchayat & 12 & 10.00 \\
\hline 3. & Political or other & 4 & 03.33 \\
\hline 4. & & & \\
\hline
\end{tabular}

Table.9 Distribution of respondents according to farm size

\begin{tabular}{|c|c|c|c|}
\hline Sl. no. & Land holding size category & Frequency & $(\%)$ \\
\hline 1. & Small $(<1 \mathrm{ha})$ & 19 & 15.83 \\
\hline 2. & Medium $(1-5 \mathrm{ha})$ & 91 & 75.84 \\
\hline 3. & Large $(>\mathbf{5 h a})$ & 10 & 8.33 \\
\hline
\end{tabular}

Table.10 Distribution of respondents according to farm size with onion crop

\begin{tabular}{|c|}
\hline Sl. no. \\
\hline 1. \\
\hline 2. \\
\hline 3. \\
\hline
\end{tabular}

Land holding size category

Small $(<0.5 \mathrm{ha})$

Medium (0.6-1.5 ha)

Large (>1.5 ha)
Frequency

(\%)

26

21.67

84

70.00

10

08.33

Table.11 Distribution of respondents according to material possession

\begin{tabular}{|c|}
\hline Sl. no. \\
\hline 1. \\
\hline 2. \\
\hline 3. \\
\hline 4. \\
\hline 5. \\
\hline
\end{tabular}

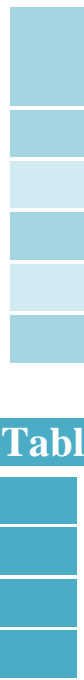

Farm Machineries

Owned

\begin{tabular}{|c|c|}
\hline $\mathbf{F}$ & $\mathbf{( \% )}$ \\
\hline 11 & 09.16 \\
\hline 41 & 34.17 \\
\hline 0 & 00.00 \\
\hline 4 & 03.33 \\
\hline 5 & 04.17 \\
\hline
\end{tabular}

$\mathbf{F}$
109
59
0
116
115

Hired

Tractor

Cart

Harvester

Thresher

Automobiles

04.17

\title{
Table.12 Distribution of respondents according to annual income
}

\begin{tabular}{|c|}
\hline Sl. no. \\
\hline 1. \\
\hline 2. \\
\hline 3. \\
\hline
\end{tabular}

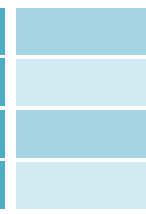

\author{
Income category \\ Low $(<50,000 \mathrm{Rs})$ \\ Medium (51,000-1.5lakh Rs) \\ High (>1.5 lakh Rs)
}

F

(\%)

07

5.83

74

61.67

40

33.33 


\section{Table.13 Distribution of respondents according to yield per hectare}

\begin{tabular}{|c|c|c|c|}
\hline SI no. & Category $(\mathbf{Q t l} / \mathbf{h e c})$ & $\mathbf{F}$ & $\mathbf{( \% )}$ \\
\hline 1. & Low $(<228)$ & 21 & 17.5 \\
\hline 2. & Medium $(228$ to 317$)$ & 80 & 66.67 \\
\hline 3. & High $(>317)$ & 19 & 15.83 \\
\hline 4. & Total & 120 & 100.00 \\
\hline
\end{tabular}

\section{Table.14 Distribution of respondents according to their Access}

\begin{tabular}{|c|c|c|c|}
\hline Sl. no. & Item & Frequency & $\mathbf{( \% )}$ \\
\hline 1. & Access to market & 119 & 99.17 \\
\hline 2. & Access to credit & 109 & 90.83 \\
\hline
\end{tabular}

The majority of the respondents $(78.33 \%)$ belonged to the medium family size i.e. (3-8), whereas $(13.33 \%)$ belonged from large family size i.e. $(<8)$ and $(13.33 \%)$ from small family i.e. (>3). The total number of family size ranges from 2 to 18 (Table 5).

The majority of the respondents 107 (i.e. $89.16 \%$ ) were dependent only on agriculture as their primary occupation other than, 4 respondents $(3.33 \%)$ were engaged with auto rickshaw driving and four respondents (3.33\%) were engaged with business along with farming. It is interesting to note that the remaining five respondents i.e. $4.17 \%$ were having government job as their primary and agriculture as secondary source of occupation (Table 6). Similar results were observed by Gadge et al., (2012), Gummagolmath (2013) and Patil et al., (2012).

Majority of 92 respondents (75.83\%) were having moderate experience (8-19 years) followed by 17 respondents (15\%) low (below 8 years) and 11 respondents $(9.17 \%)$ high experience (more than 19 years) on onion farming (Table 7).

Overwhelming majority of the respondent's i.e. $85 \%$ was not associated with any organization by any way of membership and involvement. It was noted that only $10 \%$ of the respondents were actively involved in panchayats as a member, $5.83 \%$ of the respondents were associated with the cooperative society by way of membership and involvement and $3.33 \%$ of the respondents were involved as an active members of any political organization (Table 8). Similar results were observed by Gadge $e t$ al., (2012), Gummagolmath (2013) and Patil et al., (2012).

The 98 respondents $(75.84 \%)$ had medium size (1-5 ha) of land holding followed by 19 respondents $(15.83 \%)$ small size $(<1 \mathrm{ha})$ and 10 respondents $(8.33 \%)$ had large ( $>5$ ha) land holding size (Table 9).

The 84 respondents $(70.00 \%)$ grow onion crop on medium size of land (0.6 to $1.5 \mathrm{ha}$ ) followed by 26 respondents $(21.67 \%)$ use to grow onion on small size of land i.e. (below $0.5 \mathrm{ha}$ ) and 10 respondents $(08.33 \%)$ on large size (more than 1.5 ha) (Table 10).

The $90.84 \%$ of the respondents had hired tractor and only $9.16 \%$ owned their own and the majority of the respondents $96.67 \%$ had been hiring thresher as farm machineries and only $3.33 \%$ of the remaining respondents had owned their own thresher. Similar results were observed by Gadge et al., (2012), Gummagolmath (2013) and Patil et al., (2012). It had been also noted that $95.83 \%$ of the respondents had hired automobiles and 
only $4.17 \%$ had owned their own. It has been also found from study that majority of the respondents had hired farm machineries as they were prone to necessity (Table 11).

The majority of respondents (61.67\%) belonged to medium range (Rs. 51,000$1,50,000)$ of income category followed by $(33.33 \%)$ high range (more than Rs. 1,50,000) annual income of the respondents whereas only $(5.83 \%)$ of respondents belonged to the low (> Rs. 50,000) annual income category (Table 12). Similar results were observed by Gadge et al., (2012), Gummagolmath (2013) and Patil et al., (2012).

The $66.67 \%$ of the respondents had an average medium yield between $228-31,700 \mathrm{Kg}$ $\mathrm{ha}^{-1}$ followed by $17.5 \%$ of the respondents had low yield (> 22,800 $\mathrm{Kg} \mathrm{ha}^{-1}$ ) and only $15.83 \%$ of the respondents had high yield (< $31,700 \mathrm{Kg} \mathrm{ha}^{-1}$ ) (Table 13). Almost all of the respondents (99.17\%) had an access to market and also majority of the respondents $(90.83 \%)$ had an access to credit (Table 14). Similar results were observed by Gadge et al., (2012), Gummagolmath (2013) and Patil et al., (2012).

The sociological status of onion growers in Patur block of Akola district is explored in the present study. It reveals that most of the middle age group (between 37 to 56 years) with $(71.67 \%)$ having middle level of education i.e. up to higher secondary $(89.16 \%)$ are having agriculture as their only occupation for livelihood with medium (1-5 ha) size of farm gives them income in the medium range i.e. between Rs. 50,000 to $1,00,000$. Here, it is worth mentioning that higher socio-economic status of a farmer is characterized by higher education, larger farm size, higher income, etc., which determines the source of information preferred by farmers. But, it is quite obvious that $85 \%$ of respondents were not associated with any organization by any way of membership and involvement that might leads $(66.67 \%)$ of the respondents to medium average annual yield i.e. between 22,800 to $31700 \mathrm{Kg} \mathrm{ha}^{-1}$. Also found that very majority of people had to take credit per year for farming. According to the action plan KVK, Akola, 2013-14, it was reported that onion is leading as first in area under cultivation i.e., 1600 ha and highest production of $33600 \mathrm{Kg} \mathrm{ha}^{-1}$, among all the vegetable crops grown in Akola district but the productivity of the crop is reported to be dwindling which might be due lack of information about the crop. In this context, extension services can be considered as remarkable factor for enhancing productivity. Farmers require a diverse range of information and knowledge to support their farm enterprises. Hence, convergence of extension agents is necessary to provide knowledge and create interest about the various local groups and organizations providing agriculture related information and services at local level.

\section{References}

Gadge and Lawande, (2012), Crop damage due to climatic change: A major constraint in onion farming, Indian Research Journal of Extension Education, Special Issue (2), pp: 38-41.

Gummagolmath, K.C., (2013), Research report- Trends in Marketing and Export of Onion in India, National Institute of Agricultural Marketing (NIAM) Jaipur Rajasthan, pp: 5-11.

Krishi Vigyan Kendra, Akola district Maharashtra, Action plan 2013-2014, pp: 1-5.

National Institute of Agricultural Marketing (2013): Trends in Marketing and Export of Onion in India, Research Report Jaipur, Rajasthan.

Patil., N. A. and A. H. Rajasab, (2012), Constraints Experienced by Onion 
Growers from Gulbarga District of Karnataka, India, International Journal of Extension Education (8), pp: 48-50.

Project Implementation Unit (Agricultural marketing), (2013), Akola district progress report on Maharashtra Agricultural Competitiveness Project, Akola district report $1^{\text {st }}$ midterm review, pp: 3-5.

\section{How to cite this article:}

Sudarshan C. Awatade, Anindita Saha and Digvijay S. Dhakre. 2018. Sociological Status of Onion Growing Farmers in Akola District of Maharashtra. Int.J.Curr.Microbiol.App.Sci. 7(03): 6-12. doi: https://doi.org/10.20546/ijcmas.2018.703.002 